\title{
感熱記録紙用微粉シリカの開発
}

\author{
水澤化学工業(株研究開発部 高橋 正男，田中 正範 \\ 佐藤 悌治，小川 政英
}

\section{Development of Fine Powdered Silica for Thermal Recording Paper}

\author{
Masao Takahashi, Masanori Tanaka, Teiji Sato and Masahide Ogawa \\ Research \& Development Division, Mizusawa Industrial Chemicals, Ltd.
}

\begin{abstract}
Thermal recording paper typically used in facsmile system has been rapidly expanding to great proportions and has secured a firm position in an information-oriented society. This would result the systematic development between electronic technology in hardware industries and coating technology in paper industries including various raw material industries.

The fine powdered silica, "Mizukasil", has played an important role in the development of the thermal recording paper as a residue-preventing agent on a thermal head. Since this fine powdered silica has extremely fine particles and is inactive, it combines the following advantages in residue -prevention, sticking prevention, color-developing sensisivity, color intensity, dot minuteness, color gradient and runnability of the thermal head.
\end{abstract}

Keywords : Thermal recording paper, Under coat, Thermal head, Residue-prevention, Sticking prevention, Fine powdered silica, Mizukasil P-527 and P-832

\section{1.はじめに}

ファクシミリは今や情報伝達の重要な手段の 1 つに なっており，通信技術の革新を象徴するかのように日 本はもとより全世界的に飛躍的な拡がりを見せている。

ファクシミリの技術がここに至るまでには種々の経 緯を伴っているが, ハード機器メーカーにおけるエレ クトロニクス関連の開発技術と製紙メーカーにおける 感熱記録紙開発技術のシステム化が図られ，関連する 各種素材メーカーとの一体化が生み出した結果である と言われている。

現在, 感熱記録紙の全需要量の 70 ～80\%がファクシ ミリ用で占められ, 各種プリンター用, POS ラベル用 はそれぞれ 10〜15\%と推定されている。ファクシミリ が進展してきた特徴的な背景は，メンテナンスフリー， 高信頼性，簡便性，高速性および安価であるなど今日 の社会にふさわしい条件を満たしていることが上げら れ, 情報化社会の発展に伴い今後さらに改良が加えら れながら多様化，充実化が図られていくと見られる。
記録紙の発色面を熱ペンに接触させるという感熱記 録方式において，当社で製造している微粉シリカ・商 品名「ミズカシル」は，感熱記録紙の開発当初からサー マルヘッドへのカス付着を防止する素材として重要な かかわりを持ってきた。

このシリカは粒子径が極めて微細であり，しかも不 活性であるため単にカス付着を防止するだけでなく， 発色感度, 発色濃度, ドットの精微性向上, 色調の階 調性向上，サーマルヘッドの走行性改良など数多くの 利点を有している。

本稿では感熱記録紙用として使われる微粉シリカの 機能を紹介する。

\section{2. 感熱記録紙}

現在の感熱記録方式は 1964 年に米国 NCR 社に よって開発されたものが原型といわれている。これは ノーカーボン紙に使用される無色染料とフェノール系 の酸性物質を組合せた発色型感熱記録紙で NASA 計 画にいち早く利用された ${ }^{1)}$ 。 
我が国では 1972 年にファクシミリ通信が専用線か ら公衆電話回線に開放され, 更に 1975 年の電々公社 (当時) の家庭用ファクシミリ計画が発表された頃か ら，ハードと感熱記録紙の開発に拍車がかかった。と りわけサーマルヘッドの開発は高速化と高解像化に躍 進をもたらした。1980 ’81 年頃には薄膜型および厚膜 型サーマルヘッドによる G III機の出現を見るに至り, その後は高速化・小型化に成功し現在では G IV機が作 りだされている。

一方，感熱記録紙もその用途がファクシミリだけで なくPOS システムや自動券売システムなどを含めた 各種プリンター用分野へと広がり, 感熱記録紙として の改良工夫が活発に行われた。特に, 1986 '87 年にか けては従来の単一記録層型からアンダーコート層を取 り入れた三層構造の感熱記録紙が実用化され, 高感度 化への対応がいっそう進んだ。これと同時に染料, 顕 色剂をはじめバインダー, 増感剤, 保存性向上剤, カ ス付着防止・ステッキング防止剤（サーマルヘッド走 行性改良片）など多岐に渡る感熱記録紙用薬品の開 発・改良が行われ，今なお盛んに研究が進められてい る。

図 1 には年度別の感熱記録紙の出荷数量（推定）を 示す。感熱記録紙はファクシミリの出荷台数に伴って 伸びており, '85 年以後の急激な伸びは輸出が多くなっ たことを示している。微粉シリカ・ミズカシルの感熱 記録紙に使われる出荷数量も上記の状況に応じて'80 年から使われ始めて以来順調な伸びを示している。

図 2 には感熱記録紙および感熱記録用ハードに関す

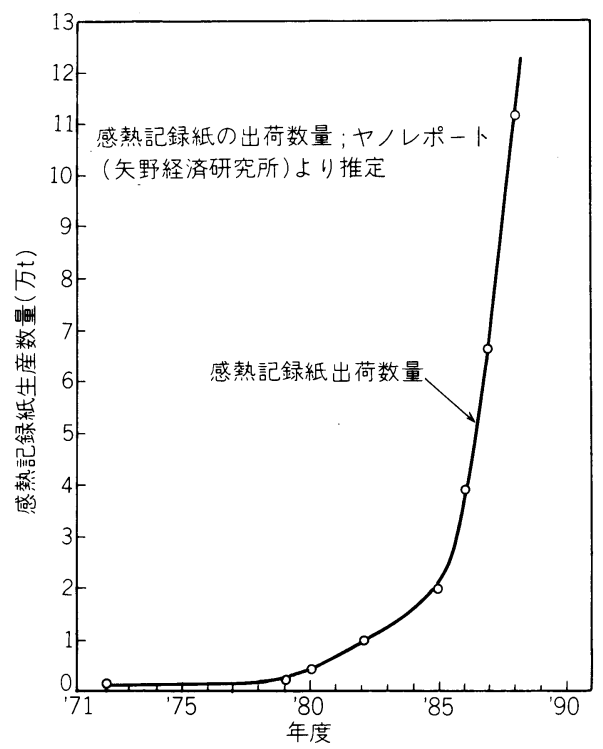

図 1 感熱記録紙の年度別出荷数量

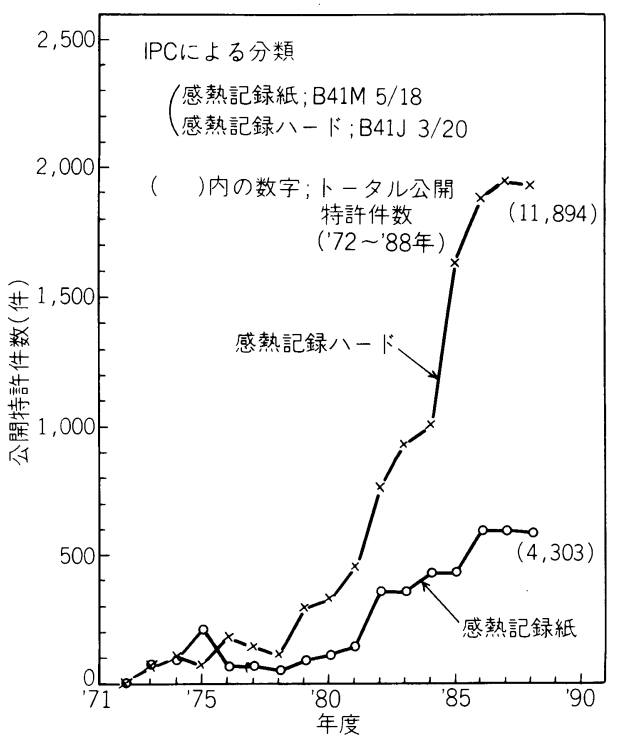

図 2 感熱記録紙及び感熱記録ハードに 関する年度別公開特許件数

る年度別公開特許件数の推移を示す。'86〜'88 年にか けて公開件数がやや横ばい傾向に変わりつつあり飽和 傾向を示している。

\section{1 記 録 機 構}

無色化ロイコ染料を利用した発色記録方式は，感圧 記録紙と感熱記録紙に代表されるが，それらはロイコ 染料（電子供与体）と顕色剂（電子受容体）との物理 的な接触方法の違いと言うことができる。また，感熱 記録紙は先に開発された感圧記録紙の主要な蓄積技術 を受け継いで発達してきたとも言える。

図 3 には代表的な感熱記録紙の構造を示す。(A)は 単一記録層型の感熱記録紙であり，（B）はアンダー コート層を設けな感熱記録紙である。後者は平滑性と

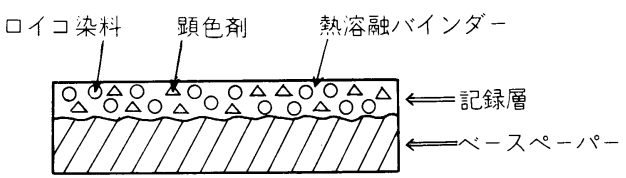

(A)単一発色層感熱記録紙

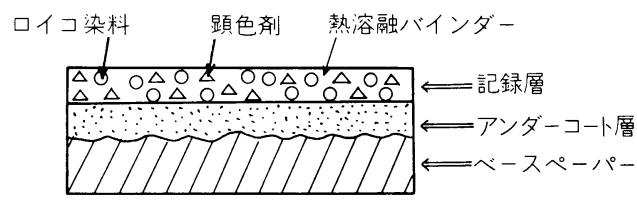

(B)アンダーコート層を設けた感熱記録紙

図 3 感熱記録紙の構造 

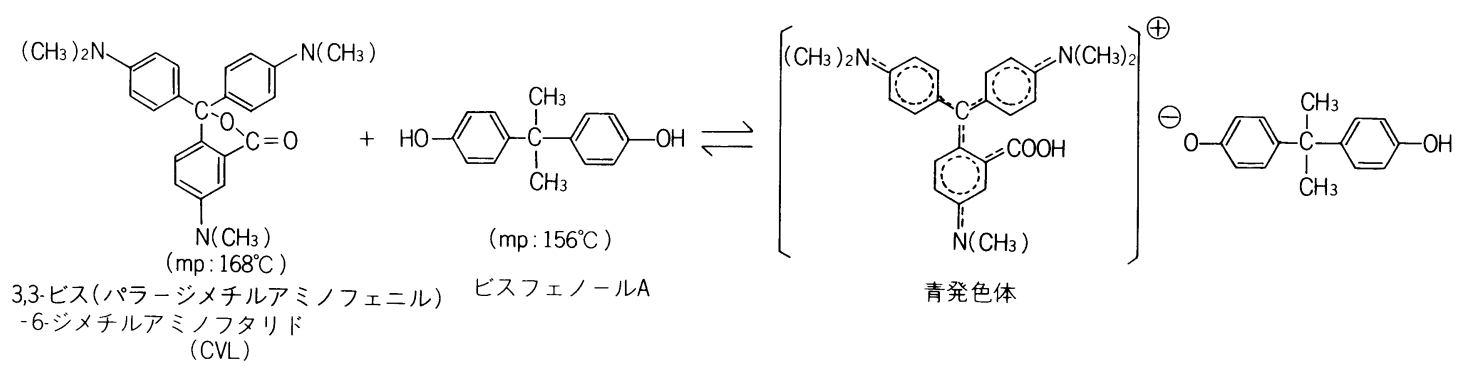

青発色体
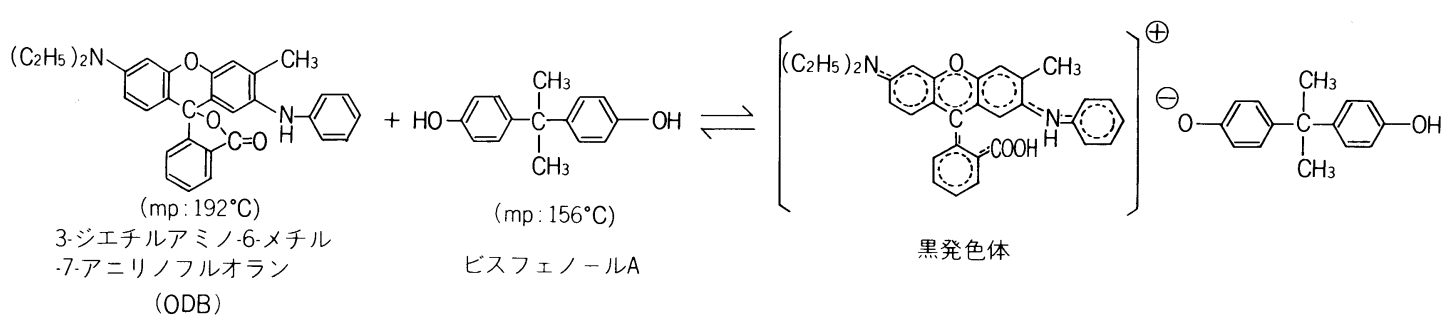

黒発色体

--・は共役系の広がりを表わす

図 $4 \mathrm{CVL}$ と ODB のビスフェノール A による発色反応機構

熱効率を改善するためのものであり，この他に保存性 を改良する目的で記録層の上にオーバーコート層を設 けな感熱記録紙もある。

通常, 記録層は口イコ染料と顕色剬が熱溶融性バイ ンダー中に固体微粒子として分離・分散された状態に あり，常温では無色である。記録時，加熱により一定 温度に達すると, 記録層は瞬時に融解しロイコ染料と 影色剂が接触し合って初めて発色することになる。

一般的には，染料分子の電子供与基から押し出され た電子が共役結合上に流れ出て広く分散し, 非局在化 すること（共鳴混成体の形成）による分子内電荷移動 型の発色機構である。

図 4 には代表的な青発色と黒発色の例を示す。すな わち CVLなどのラクトン系ロイコ染料や ODBなど のフルオラン系ロイコ染料のように, 分子内にラクト ン環を持つことによって無色化された染料（電子供与 体) が, ビスフェノール Aのようにフェノール性水酸 基を有する固体酸型顕色剈（電子受容体）に電子を供 与する (=プロトンを受容する) ことによりラクトン 環の開裂を伴なって発色する。

現在, 感熱記録紙はほとんど黒発色が主体であり, $2 \sim 3$ 色のマルチカラー化も期待されている。しかし, インクジェット記録や感熱転写記録のようなフルカ ラー化は原理的に困難と見られている。

\section{2 感熱記録紙の要求特性と微粉シリカの役割}

微粉シリカ・ミズカシルが感熱記録紙用に使われて 来たことは先に述べたが,ここでその基本的な微粉シ
リカの役割を説明する。

ファクシミリの規格が G I 型から G III型へ移行し, 記録速度は数分から 10 秒程度 (A 4 標準原稿) まで短 縮された。最近出回りはじめたG IV型では 3 4 秒の 高速記録が可能と言われている。この高速化への移行 過程で, サーマルヘッドと感熱記録紙表面の間で生じ るカス付着, ステッキング, サーマルヘッドの摩耗や 腐食などの各種トラブルを改善することが求められた。 特に, カス付着は加熱時に溶融状態にある発色物質な どがサーマルヘッドに転移付着するものであり, 連続 記録中に次第に堆積して熱伝導に極めて悪い影響を与 え，記録画質が不鮮明になったり濃度の低下をもたら す原因となる。また，ステッキングはサマルヘッド と感熱記録紙表面がカス付着現象と同じように熱溶融 物によって粘着やべトつきの現象を起こすもので, 紙 送りがスームズにゆかなくなり記録画像の乱れをひき 起こす原因となる。

これらの問題を解決するために, 記録層中に炭酸力 ルシウム, クレー, タルク, 尿素-ホルマリン樹脂そし て微粉シリカなどの吸油性填料を添加する方法が知ら れている2)。しかし, 感熱記録特性やへッドマッチンク 性などの総合面から評価した時, 微粉シリカの中でも ミズカシルが最も適した填料であることが分かっ だ) 。方。のミズカシルは熱溶融物を吸収することに よって，上記のトラブル発生を抑制するだけでなく同 時に滑剤としての機能も有しており, サーマルヘッド の走行性を良好に保つ作用がある。 
以下に感熱記録紙用塡剤であるミズカシル $\mathrm{P}-527$ と P-832を使用した場合の特徴を示す。

（1）白色度の高い感熱記録紙が得られ，地肌污れが ない

ミズカシル $\mathrm{P}-527, \mathrm{P}-832$ は感熱記録紙層を隐ぺい 率の高い白色の被塗面とする。また，これらのミズカ シルは比表面積を極端に小さく制御してあり, 表面活 性点を大幅に少なくしてある。従って, 感熱塗液の調 製時, 記録紙の乾燥時やカレンダリング時あるいは記 録前後の保存時における自然発色（地肌污れ）は著し く抑制される結果となる。

(2) カス付着の防止とステッキングの防止

ミズカシル P-527, P-832 は超微粒子でありしかも 吸油量が大きく, 記録層の熱溶融物を瞬時に粒子間の 空隙に吸収保持する。その結果, サーマルヘッドへの 溶融カスの付着は全く起こらず, サーマルヘッドと感 熱記録紙表面の間の溶融物による粘着やべトつきなど のステッキングも起こらない。

（3）サーマルヘッドの摩耗や腐食がなく，走行性に 優れる

ミズカシル P-527, P-832 のモース硬度は約 1 程度 と柔かいシリカであり, タルクに似たスリップ性を示 す。また，超微粒子であるため平滑性に優れた被塗面 を作り, サーマルヘッドを摩耗させることがなく走行 性も良好となる。さらに, サーマルヘッドを腐食させ る原因と考えられている $\mathrm{Na}^{+}, \mathrm{K}^{+}, \mathrm{Li}^{+}$などのアルカ リ金属イオンや $\mathrm{F}^{-}, \mathrm{Cl}^{-}$などの陰イオンについても, ミズカシル P-527, P-832 に含まれる量は極端に少な くサーマルヘッドを腐食することはない。
（4）感熱発色特性の向上

ミズカシル P-527，P-832 を用いた感熱記録紙は熱 に対する発色感度（熱応答性）の向上につながり，し かも発色濃度も高く優れたものとなる。この良好な発 色感度は加熱時のロイコ染料と顕色剂, そして増感剤 を含めた融点降下にもとづく低温融解反応によるもの と考えられる。P-527 や P-832 は感熱記録層内では他 の﨏料に比べ含有量も少なくて済み，しかも微細で均 一な分散状態をなすため口イコ染料と顕色剂は容易に 接触反応し, しかも発色溶融体は近傍のシリカ粒子に すばやく吸収されることになる。そして，その発色溶 融体はシリカ粒子表面に濃縮され粒子を被覆する状態 で存在するため, この発色層とシリカの界面では多重 の散乱と反射が生じて, 発色感度を阻害することなく

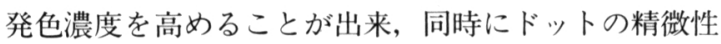
向上にも役立つものと考えられる。

（5）アンダーコート層での使用

アンダーコート層は高感度化のために設けられるが, 現在各製紙メーカーではほとんどこの方式を採ってい る。一般的に使用される填料としては焼成カオリン, 炭酸カルシウム, 有機発泡体勇そして微粉シリカ・ミズ カシル $\mathrm{P}-527^{6)}$ などが知られている。

ミズカシル P-527をアンダーコート層と記録層に 用いた感熱記録紙は表面平滑度も高く，発色感度と到 達濃度共に優れたものになる。

写真 1,2 には現在市場に出回っている代表的な感熱 記録紙の表面及び断面の走查型電子顕微鏡写真を示す。

写真 1 はアンダーコート層, 記録層ともにミズカシ

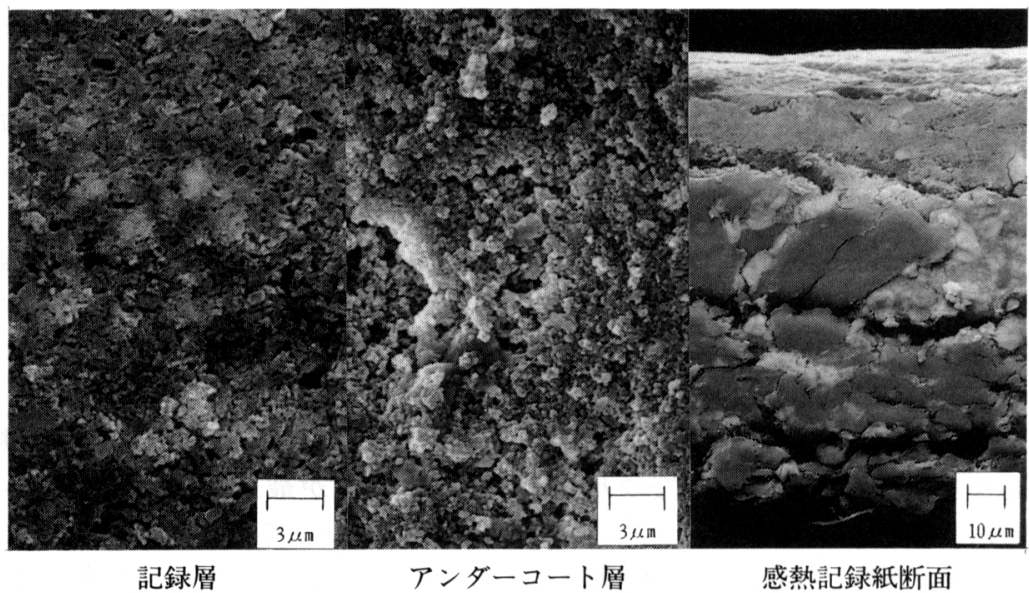

写真 1 ミズカシル P-527 をアンダーコート層と記録層に使用した感熱 記録紙 


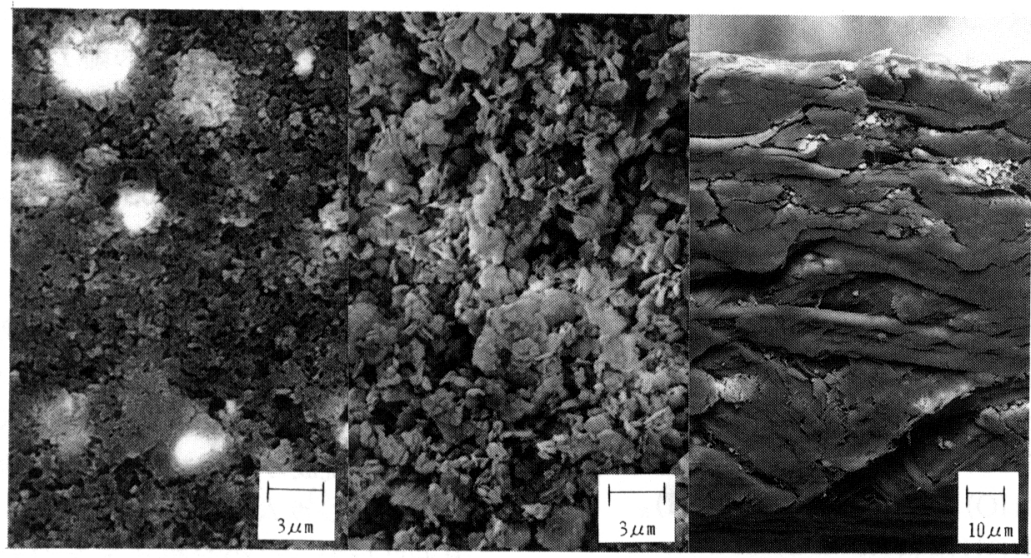

記録層

アンダーコート層

感熱記録紙断面

写真 2 焼成カオリンをアンダーコート層に使用し, ミズカシル P-527 と 炭酸カルシウムを記録層に使用した感熱記録紙

ル P-527 を使用している例, 写真 2 はアンダーコート 層に焼成カオリンを使用し，記録層にはミズカシル $\mathrm{P}$ -527 と炭酸カルシウムを混合して使用しな感熱記録 紙の例を示す。

\section{3. 感熱記録紙用微粉シリカについて}

感熱記録紙用微粉シリ力は不活性でしかも嵩高い超 微粒子であることが必要である。一般的に知られてい るホワイトカーボンの製造方法8)では, 得られるシリ 力の 2 次粒子径が大きくしかも比表面積が $100 \mathrm{~m}^{2} / \mathrm{g}$ 以上と大きいため, 感熱塗液を調合する段階でこのシ リカ粒子が顕色剂として働き, 感熱塗液がすでに着色 してしまうという久点がある。

\section{1 感熱記録紙用微粉シリカの製造方法}

感熱記録紙用微粉シリカであるミズカシル P-527, P-832の製造方法 ${ }^{35)}$ は以下のごとくである。

ミズカシル P-527 と P-832 はいずれも濃厚な金属 塩溶液中において，ケイ酸ナトリウムと鉱酸又はケイ 酸ナトリウムとアルカリ土類金属塩との反応によって 得られる。金属塩溶液としては無機酸又は有機酸のア ルカリ金属塩などが単独又は 2 種以上の組合せで使用 出来る。

R. K. Iler ${ }^{9)}$ によと, ケイ酸ナトリウムにはモノシ リケートイオン, ポリシリケートイオンそしてコロイ ド状シリカイオンミセルなどが含まれており, ケイ酸 イオン種としては $\mathrm{HSiO}_{3}{ }^{-}, \mathrm{Si}_{2} \mathrm{O}_{5}{ }^{2-}, \mathrm{SiO}_{3}{ }^{2-}, \mathrm{SiO}_{4}{ }^{4-}$ な どの存在が知られている。これらのケイ酸イオンが鉱 酸やアルカリ土類金属塩によって分解し，急速に縮合 一脱水を始め高分子ケイ酸へと縮重合によって成長す ることになる。
図 5, 6にはケイ酸イオンの縮重合の過程を示す9)。 通常, 湿式法によって得られる沈降性夕イプの微粉 ケイ酸やホワイトカーボンはシリカの一次粒子径が 10 - 30 nmであり，これらの一次粒子がやや強く凝集 した二次粒子径は $2.5 \sim 10 \mu \mathrm{m}$ と大きくなるのに対し て, ミズカシル P-527 や P-832 は一次粒子径が 40 〜 $100 \mathrm{~nm}$ と大きく, また表面活性も小さいために一次 粒子同士の凝集力は弱く，二次粒子径としては 0.5 $\sim 2.5 \mu \mathrm{m}$ と小さくなる。これは図 5,6 に示した縮重 合過程においてミズカシルの場合, 縮重合がゆっくり

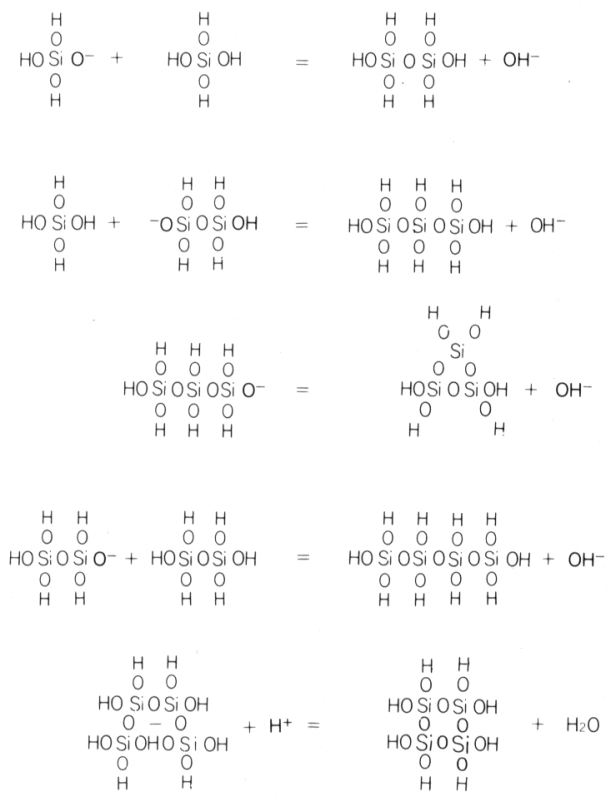

図 5 予想されるシリカの重合ステップ 


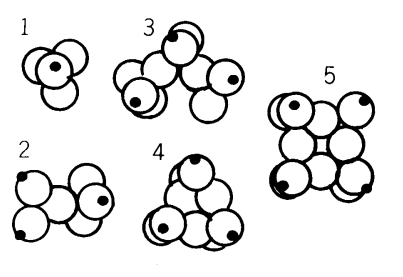

図 6 Silicic Acidの分子モデル

$1: \mathrm{Si}(\mathrm{OH})_{4}$

$2:(\mathrm{HO})_{3} \operatorname{SiOSi}(\mathrm{OH})_{3}$

$3:(\mathrm{HO})_{3} \mathrm{SiOSi}(\mathrm{OH})_{2} \mathrm{OSi}(\mathrm{OH})_{3}$

$4:\left\{(\mathrm{OH})_{2} \mathrm{SiO}_{3}\right.$

$5:\left\{(\mathrm{OH})_{2} \mathrm{SiO}_{4}\right.$

$\bigcirc$ : 酸素原子, ・ : 水素原子

ケイ素原子は酸素原子の正

四面体の中心に位置するた

め見えない
と進むのではなく瞬時に縮重合が進んで高ポリマー化 したものと考えられる。

3.2 微粉シリカ・ミズカシルの物理的, 化学的性状 微粉シリカ・ミズカシル P-527, P-832 および $\mathrm{P}-527$ の変性タイプである P-603, P-527H の物理的, 化学的 性状を表 1 に示す。

感熱記録紙用のミズカシル P-527，P-832，P-603， $\mathrm{P}-527 \mathrm{H}$ などのモース硬度は約 1 であり, 普通の微粉 ケイ酸やホワイトカーボンのモース硬度 $1.5 \sim 2.0$ と 比較するとかなり柔かいシリカ粉末であると言える。 ちなみに, 焼成カオリンのモース硬度は $3.0 \sim 3.5$, 軽 質炭酸カルシウムは $2.5 \sim 3.0$ である。

P-603 は P-527 の見掛比重をやや重く仕上げた夕 イプで，塗液に分散させる時に粘性が高くならず高濃 度化が図れる製品である。逆に P-527H は P-527をや や軽く仕上げたタイプで発色感度とカス付着防止性能 を改善した製品である。

シラノール基密度はシリカ粒子の外部と内部表面の シ $\mathrm{Si}-\mathrm{OH}$ 密度を表すものであるが，ここでは簡便法

表 1 感熱記録紙用ミズカシルの物理的, 化学的性状

\begin{tabular}{|c|c|c|c|c|c|c|}
\hline & $\begin{array}{c}\text { ミズカシル } \\
\text { P-527 }\end{array}$ & $\begin{array}{c}\text { ミズカシル } \\
\text { P-832 }\end{array}$ & $\begin{array}{c}\text { ミズカシル } \\
\text { P-603 }\end{array}$ & $\begin{array}{c}\text { ミズカシル } \\
\mathrm{P}-527 \mathrm{H}\end{array}$ & $\begin{array}{c}\text { ホワイト } \\
\text { カーボン }\end{array}$ \\
\hline \multicolumn{2}{|c|}{ 真 比重 } & \multicolumn{5}{|c|}{$1.95 \sim 2.10$} \\
\hline \multicolumn{2}{|c|}{ モース硬度*11 } & 1 & 1 & 1 & 1 & $1.5 \sim 2$ \\
\hline \multicolumn{2}{|c|}{ 白色度（\%） } & 97 & 97 & 97 & 97 & 97 \\
\hline \multicolumn{2}{|c|}{ 水 分 $(\%)$} & 4.8 & 5.0 & 4.5 & 5.3 & 8.3 \\
\hline \multicolumn{2}{|c|}{$\mathrm{pH}$} & 6.70 & 10.31 & 7.18 & 7.43 & 5.36 \\
\hline \multicolumn{2}{|c|}{ 見掛比重 } & 0.190 & 0.185 & 0.214 & 0.160 & 0.166 \\
\hline \multicolumn{2}{|c|}{ 吸油量 $(\mathrm{m} l / 100 \mathrm{~g})$} & 150 & 137 & 110 & 183 & 210 \\
\hline \multicolumn{2}{|c|}{ 分散性 $(\mu \mathrm{m})^{* 2)}$} & $15 \sim 20$ & $17 \sim 21$ & $17 \sim 23$ & $15 \sim 20$ & 100 以上 \\
\hline \multicolumn{2}{|c|}{ 平均粒径 $(\mu \mathrm{m})^{* 3)}$} & 1.75 & 1.80 & 2.06 & 1.67 & 6.20 \\
\hline \multicolumn{2}{|c|}{ 比表面積 $\left(\mathrm{m}^{2} / \mathrm{g}\right)^{* 4)}$} & 55.6 & 54.1 & 52.0 & 58.0 & 167.5 \\
\hline \multicolumn{2}{|c|}{ 細孔容積 $(c c / g)^{* 5)}$} & 0.106 & 0.224 & 0.095 & 0.110 & 0.432 \\
\hline \multicolumn{2}{|c|}{ シラノール基密度 $\left.\left(\mathrm{OH} \text { 数 } / \mathrm{nm}^{2}\right)^{* 6}\right)$} & 29.6 & 47.0 & 34.2 & 29.2 & 11.6 \\
\hline \multirow{4}{*}{$\begin{array}{l}\text { 化 } \\
\text { 学 } \\
\text { 組 } \\
\text { 成 } \\
(\%)\end{array}$} & Ig-Loss & 4.65 & 7.21 & 5.03 & 4.80 & 5.52 \\
\hline & $\mathrm{SiO}_{2}$ & 95.10 & 84.10 & 94.61 & 94.93 & 91.60 \\
\hline & $\mathrm{R}_{2} \mathrm{O}_{3}{ }^{* 71}$ & 0.14 & 0.88 & 0.20 & 0.20 & 1.33 \\
\hline & $\mathrm{CaO}$ & 0.04 & 6.76 & 0.06 & 0.04 & 0.04 \\
\hline
\end{tabular}

*11 表面のきれいなモース硬度既知の 2 板の同質板の間に測定試料をはさみ, 両方の板を磨き合わせて板に傷がつくかどうか調べ る。傷がつく場合，板の硬度より試料が硬いことを意味するので，モース硬度のより高い板を選び同様の操作をくり返し，板が 傷つく一傷つかないの接点を見い出し!これをモース硬度として表示する。

*2) JIS K 5400.4.4に従いつぶゲージを用いて測定

${ }^{* 3)}$ Coulter Counter TA-II (AP 径 $\left.50 \mu \mathrm{m}\right)$ によるメジアン径

*4).5) BET 法による

${ }^{* 6)} \operatorname{Ig}$-Loss $\left(110 \sim 1,000^{\circ} \mathrm{C}\right)$ と比表面績から算出

${ }^{* 71} \mathrm{R}_{2} \mathrm{O}_{3}=\mathrm{Al}_{2} \mathrm{O}_{3}+\mathrm{Fe}_{2} \mathrm{O}_{3}$ 
として $110 \sim 1,000^{\circ} \mathrm{C}$ の Ignition-Loss 2 個の シ $\mathrm{Si}-\mathrm{OH}$ 基から 1 個の $\mathrm{H}_{2} \mathrm{O}$ 分子が脱離するものと 見なし，それを比表面積で除して算出した。P-527, P -832などはいずれも高いシラノール基密度を示して いるが，このことが小さな比表面積であるにもかかわ らず嵩高いシリカ粉末であるという特徵と関係がある。 粒子内部のシラノール基は三次元的な $-\mathrm{S}_{1} \mathrm{i}-\mathrm{O}-\mathrm{S}_{1} \mathrm{i}-$ 結合の切断を意味するもので，それは一O- $\mathrm{Si}-\mathrm{OH}$ のような形で表わされる。一方, 表面のシラノール基 は粒子と粒子の結合に関与しー $-\mathrm{Si}_{1}-\mathrm{O}<\mathrm{H} \backslash \mathrm{H}-\mathrm{H}-\mathrm{Si}-$ のような水素結合 (-..-) を形成する。このことからシ ラノール基密度が高いということはシリカ粒子の充填 構造がラフになり易く, 従って嵩高い粉末となる。

図 7，8にはBET 吸着法によって求めた P-527 と P-832の細孔分布困を示す。

いずれも細孔容積は小さく細孔分布のピークも細孔 半径 $10 \AA$ 付近にシフトしている。ロイコ染料やその発

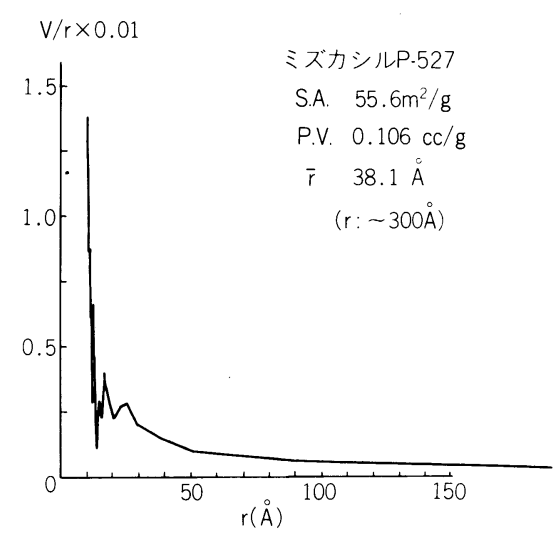

図 7 ミズカシル P-527 の細孔分布図

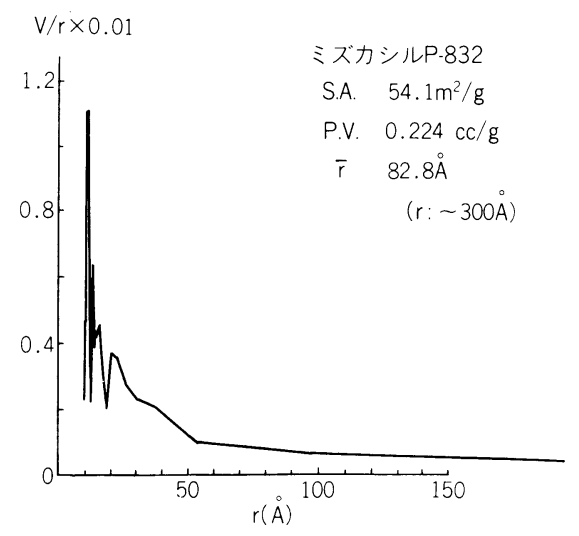

図 8 ミズカシル P-832 の細孔分布困
色体は分子量が大きいのでこのミクロポア中には入ら ない。

図 9 には P-527, P-832, P-603 および $\mathrm{P}-527 \mathrm{H} の$ Coulter Counter 法によって求めた粒度分布図を示す。 また，図 10 には P-527，P-832，P-603 の水分散に おけるシリカ濃度と粘度の関係を示す。

これら上記の性質は感熱記録の発色特性の向上や力 ス付着防止効果の向上に結びついているものと推察さ れる。

\section{4. 微粉シリカ・ミズカシルを用いた感熱記録 特性}

感熱記録特性の評価試験として, 微粉シリカ・ミズ カシル P-527 の他にホワイトカーボン, 焼成カオリ ン，炭酸カルシウムを用いて記録紙を作成し，その記 録紙の表面平滑度, 地肌污れ, 保存性, 力又付着防止 効果および印字特性などを調べた。

記録紙は単一記録層型の感熱記録紙とアンダーコー 卜層を設けた感熱記録紙の 2 種類を作成した。

表 2 には 4 種類の各填料の粉末性状を示す。

また写真 3〜 7 には各填料の走査型電子顕微鏡写真 を示す。

ミズカシル P-527, P-832の 1 次粒子や 2 次粒子の 特徴とホワイトカーボンのそれとは大きく異なってい る。また，焼成カオリンと炭酸カルシウムはそれぞれ 特徴的な形状を示しているが, ミズカシルに比べ粒子 径がかなり大きいことが分かる。

\section{1 記録紙の調製方法}

(1) 単一記録層型の感熱記録紙

染料としてフルオラン系ロイコ染料, 顕色剂として ビスフェノールA, 増感凬としてステアリン酸アミド, 滑剤としてステアリン酸亜鉛を用いて，それぞれ別々 にポリビニルアルコール水溶液中にて湿式粉砕を行い, それぞれの平均粒子径を $3 \mu \mathrm{m}$ 以下 (Coulter Counter 法, AP. tube $50 \mu \mathrm{m}$ 使用) になるように調整した。

これらの各粉砕液を著者等の標準試験処方に基づき 所定量配合し，予水に分散しておいた填料のスラ リーを全体の固型分濃度が 20 重量パーセントとなる ように混合し，感熱塗液とした。

この感熱記録塗液を坪量約 $45 \mathrm{~g} / \mathrm{m}^{2}$ の上質紙上に コーティングロッドを用いてコート量が約 $5 \mathrm{~g} / \mathrm{m}^{2}$ に なるように塗布し, 風乾後ロール圧 $5 \mathrm{~kg} / \mathrm{cm}^{2}$ でカレ ンダリングを行い，単一記録層型の感熱記録紙とした。

(2) アンダーコート層を設けた感熱記録紙

アンダーコート用填料としてミズカシル P-527 又 は焼成カオリンを用いた。また, 塗液は填料：バイン 

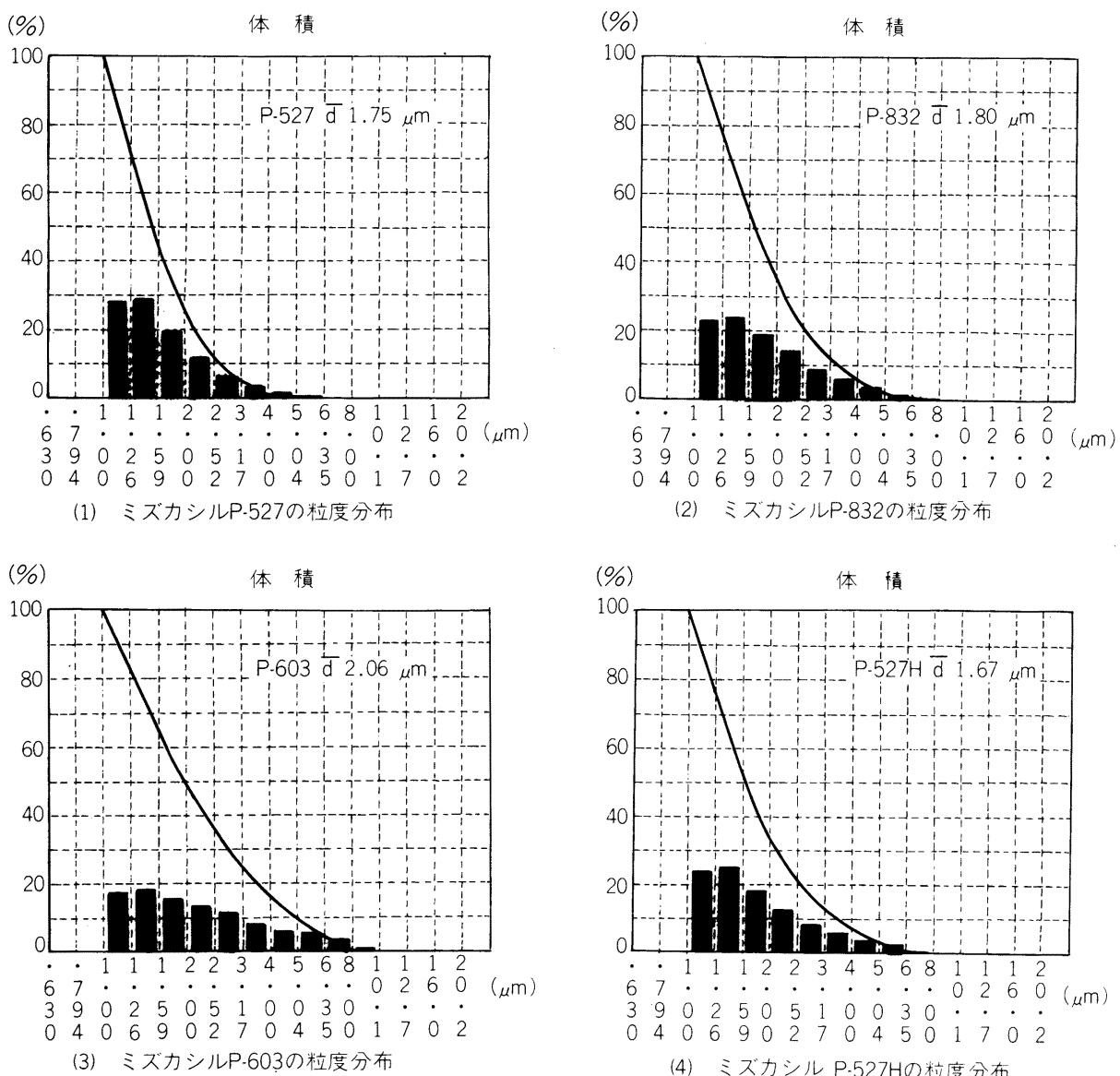

図 9 感熱記録紙用ミズカシルの粒度分布 Coulter Counter Model TA-II, AP 径 $50 \mu \mathrm{m}$

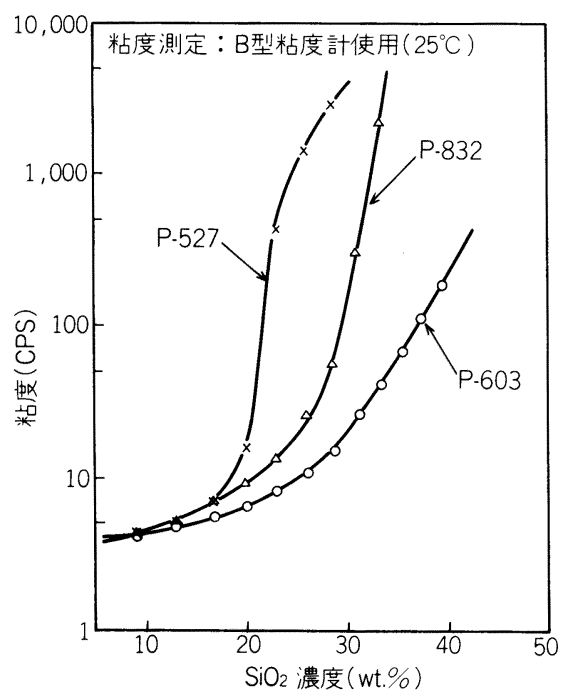

図 10 ミズカシル $\mathrm{P}-527, \mathrm{P}-832$ 及び $\mathrm{P}-603$ の水分 散におけるシリカ濃度と粘度の関係
ダーの固型分比が 0.2 になるように填料を SBR (スチ レンブタジエンラバー分散液）に高速ディスパーを用 いて分散し作成した。

これを坪量約 $45 \mathrm{~g} / \mathrm{m}^{2}$ の上質紙にコーティング ロッドを用いてコート量が約 $6 \mathrm{~g} / \mathrm{m}^{2}$ になるように塗 布し, 風乾後ロール压 $10 \mathrm{~kg} / \mathrm{cm}^{2}$ でカレンダリングを 行い, JIS P-8119の方法によるベック平滑度が 400 〜500 秒になるように調整し, アンダーコート紙とし た。

このアンダーコート紙の上に, 前記(1)の感熱塗液を 同様の方法でコーティングロッドを用いてコート量が 約 $5 \mathrm{~g} / \mathrm{m}^{2}$ になるように塗布し, 風乾後ロール圧 $5 \mathrm{~kg} /$ $\mathrm{cm}^{2}$ でカレンダリングを行い, アンダーコート層を設 けた感熱記録紙とした。

\section{2 発色特性およびカス付着防止の評価結果}

前記(1)，(2)で得られたそれぞれの記録紙の特性を次 の装置を用いて調べた。 
表 2 実験に使用した各域料の粉末性状

\begin{tabular}{|c|c|c|c|c|}
\hline & $\begin{aligned} \text { ミズカシル } \\
\text { P-527 }\end{aligned}$ & $\begin{array}{l}\text { ホワイト } \\
\text { カーボン }\end{array}$ & $\begin{array}{l}\text { 感熱記録紙用 } \\
\text { 焼成カオリン }\end{array}$ & $\begin{array}{l}\text { 感熱記録紙用軽質 } \\
\text { 炭酸カルジムム }\end{array}$ \\
\hline 水 分 $(\%)$ & 4.8 & 8.3 & 0.3 & 0.2 \\
\hline $\mathrm{pH}$ & 6.70 & 5.36 & 6.90 & 11.68 \\
\hline 见掛比重 & 0.190 & 0.166 & 0.333 & 0.478 \\
\hline 吸油量 $(\mathrm{ml} / / 100 \mathrm{~g})$ & 150 & 210 & 58 & 37 \\
\hline $\begin{array}{l}\text { Coulter Counter 法による } \\
\text { 平均粒径 }(\mu \mathrm{m})\end{array}$ & 1.75 & 6.20 & 1.80 & 5.27 \\
\hline $\begin{array}{l}\mathrm{BET} \text { 法による } \\
\text { 比表面績 }\left(\mathrm{m}^{2} / \mathrm{g}\right)\end{array}$ & 55.6 & 167.5 & 18.7 & 13.5 \\
\hline
\end{tabular}

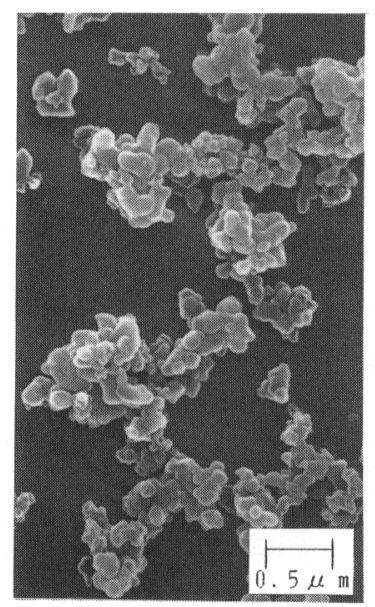

写真 3 ミズカシル P-527

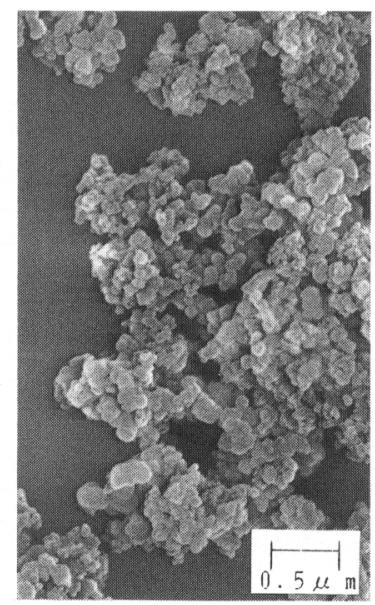

写真 4 ミズカシル $\mathrm{P}-832$

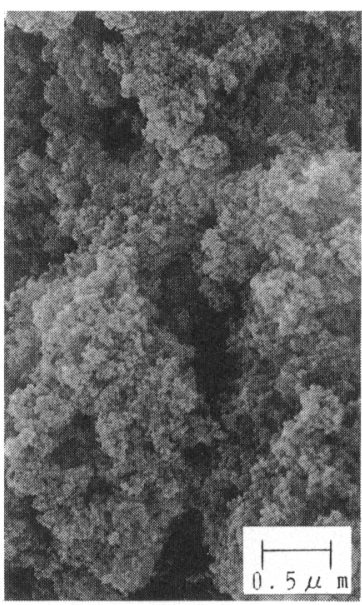

写真 5 ホワイトカーボン

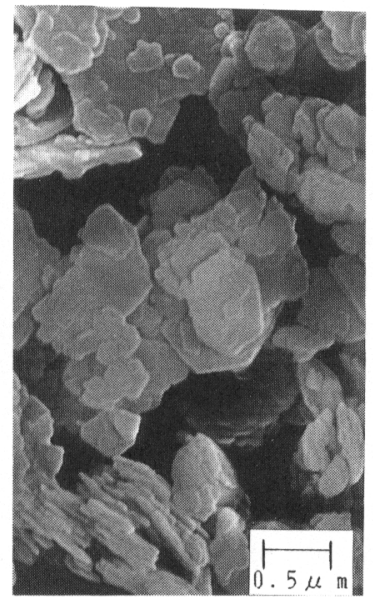

写真 6 焼成カオリン

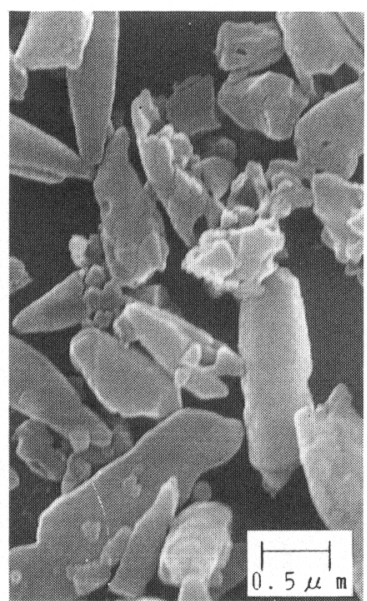

写真 7 炭酸カルシウム 
表 3 単一記録層型感熱記録紙の特性評価結果

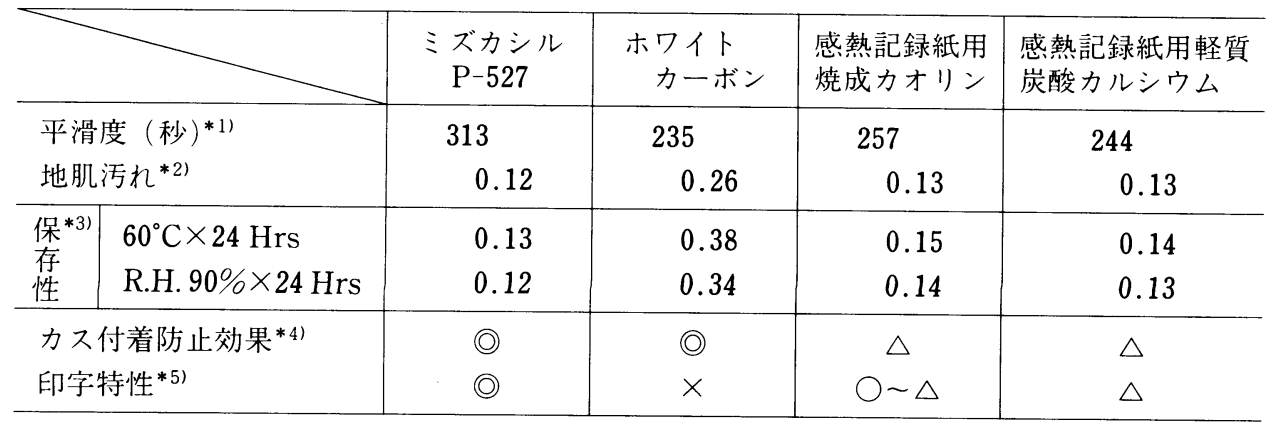

*11ベック平滑度試験機（東洋精機製）を用い，JIS P 8119 に基づいて測定

${ }^{* 21.3)}$ Fuji Standard Densito meter FSD-103 (富士写真フィルム製) を用い，白地部分の発色濃度を測定

*4) ベ夕印字後のサーマルヘッドに付着するカスを肉眼で観察, また印字面と印字面の間の白地部分にバラまか れる点々状のカスの有無を肉眼で観察

(): 優, ○:良, $\triangle$ : やや不良, $\times$ : 不良

*5) 発色感度, 高エネルギー下での到達濃度を総合評価, また地肌污れも評価

(ㅇ):優，○：良， $\triangle$ : やや不良， $\times$ : 不良

\section{(1)動的発色特性}

感熱印字装置 TH-PMD (大倉電機製)

印字条件：サーマルヘッド抵抗値 $2,651 \Omega$

$\begin{array}{lr}\text { 印字電圧 } & 24 \mathrm{~V} \\ \text { パルス周期 } & 2 \mathrm{mSec} . \\ \text { 印字パルス幅 } & 0.5 \sim 1.5 \mathrm{mSec} .\end{array}$

印字濃度の測定 ; Fuji Standard Densitometer

FS D-103

(富士写真フィルム製)

(2)力ス付着防止

NTT FAX-510 T—べ夕印字後のサーマル ヘッドに付着するカスを肉眼で観察した。

印字面へのカス付着— $1 \mathrm{~cm} \times 1 \mathrm{~cm}$ の正方形のべ 夕印字面を $3 \mathrm{~mm}$ 間隔で上下左右に配列したテストパ ターン紙を作り，これを各記録紙に印字させることに よって，白地部分（無印字部分）に記録紙の移動方向 に添って現われる小さな黒い点々状の再付着するカス の様子 (カスのバラまき) を肉眼で観察した。

（1）単一記録層型の感熱記録紙

図 11 には各媜料を用いた単一記録層型の感熱記録 紙の動的発色特性を示す。

表 3 には各填料による感熱記録紙の特性評価結果を 示す。

ミズカシル P-527を用いた記録紙は他の填料に比 べ平滑度が高く, 地肌污れ, 保存性, カス付着, 印字 特性 (発色感度, 高エネルギー下での到達濃度) とも に良好であった。ホワイトカーボンは表面活性がコン トロールされていないため地肌污れが大きく，また粒 子径が大きいため平滑度も低く, 保存性も不良であっ

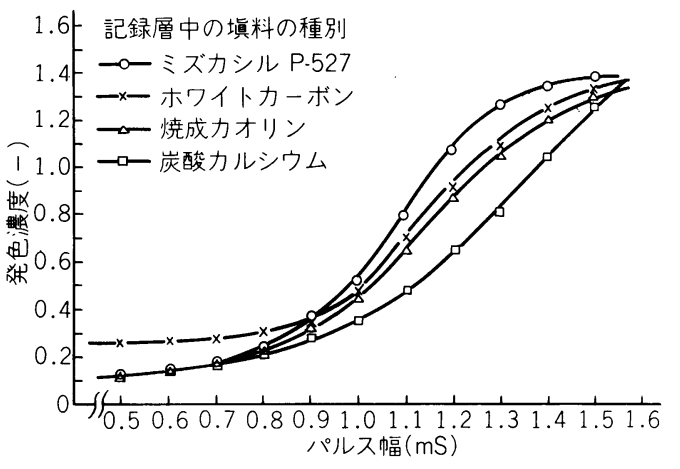

図 11 単一記録層型感熱記録紙の動的発色特性

た。しかし，吸油量が大きいのでサーマルヘッドへの カス付着は無かった。

焼成カオリンと炭酸カルシウムは印字特性が劣って おり，また吸油量が小さいためサーマルヘッドへのカ ス付着が見られた。

写真 8〜10にはサーマルヘッドの拡大写真を示す。

写真 8 は填料を使用せずに作成した記録紙を印字し た場合のサーマルヘッドの様子である。カスの付着が 極めて多く発生し, また印字面の記録濃度も低く白地 の無印字部分には点々状の黒いカスが多くバラまかれ ている。これは紙自体の污れが大きく目立ち，とても 長期間の使用には耐えられないものである。

写真 9 は填料としてミズカシル P-527を用いた記 録紙の場合で, サーマルヘッドへのカス付着は全く起 こらず，印字面も記録濃度が高く白地の無印字部分へ のカスのバラまきは見られなかった。

写真 10 は填料として炭酸カルシウムを用いた記録 


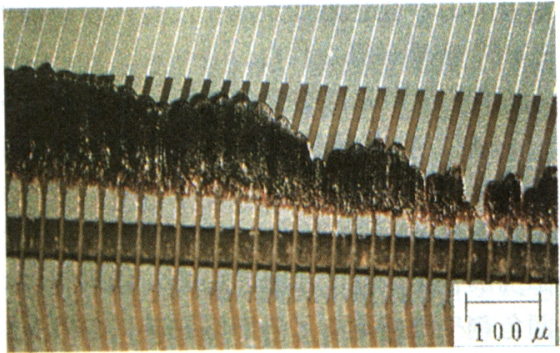

写真 8 填料無添加の感熱記録紙を印字 した場合のサーマルへッドへの カ又付着

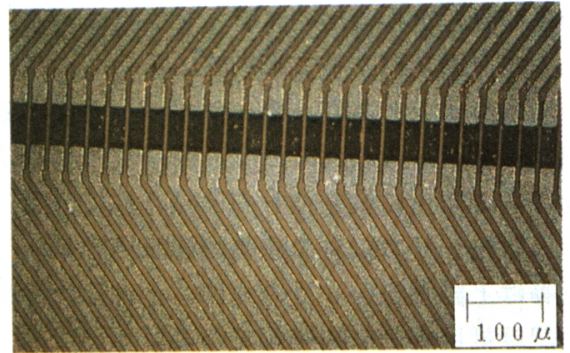

写真 9 ミズカシル $\mathrm{P}-527$ を用いた感熱 記録紙を印字した場合のサーマ ルへッドへのカス付着

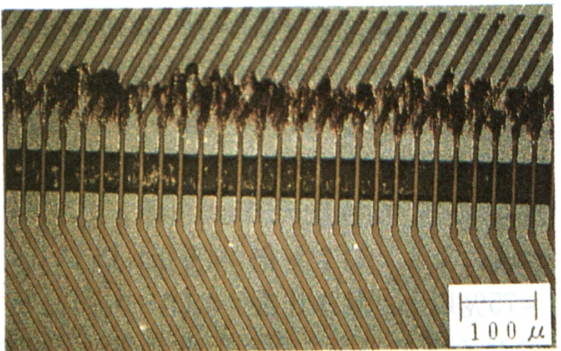

写真 10 炭酸カルシウムを用いた感熱記 録紙を印字した場合のサーマル ヘッドへのカス付着

紙の場合で，サーマルヘッドへのカス付着が見られた。 また印字面の記録濃度は低く白地の無印字部分への力 スのバラまきも多く出た。焼成カオリンの場合も炭酸 カルシウムと同様な結果であった。

（2）アンダーコート層を設けた感熱記録紙

記録層にホワイトカーボンを用いた場合の試験は地 肌污れが大きいため，ここでは省いた。

図 12 にはミズカシル P-527をアンダーコート層に 用い, 各填料を記録層に用いた感熱記録紙の動的発色 特性を示す。
図 13 には焼成カオリンをアンダーコート層に用い, 各填料を記録層に用いた感熱記録紙の動的発色特性を 示す。

また，図 14 には記録層にミズカシル P-527 を使用

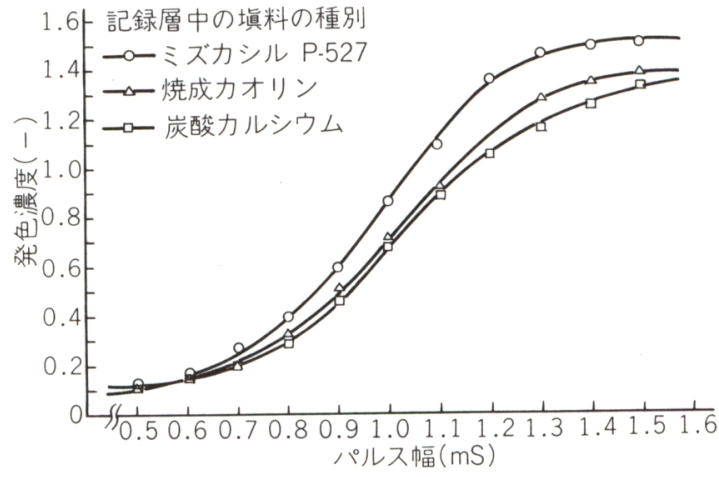

図 12 ミズカシル P-527 をアンダーコート層に 用いた感熱記録紙の動的発色特性

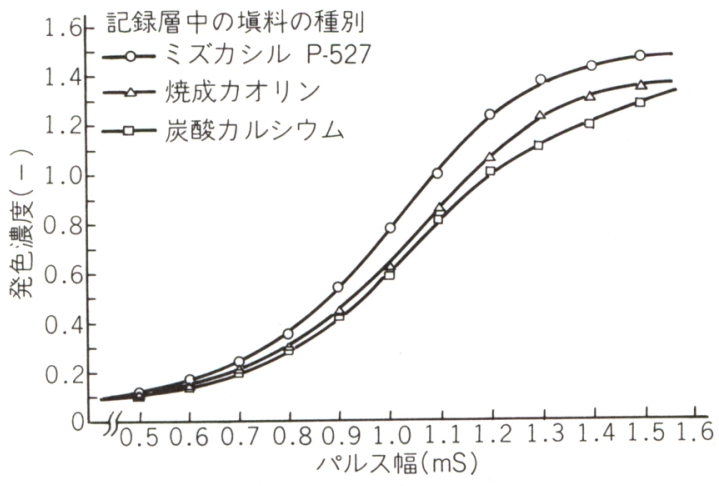

図 13 焼成カオリンをアンダーコート層に用い た感熱記録紙の動的発色記録特性

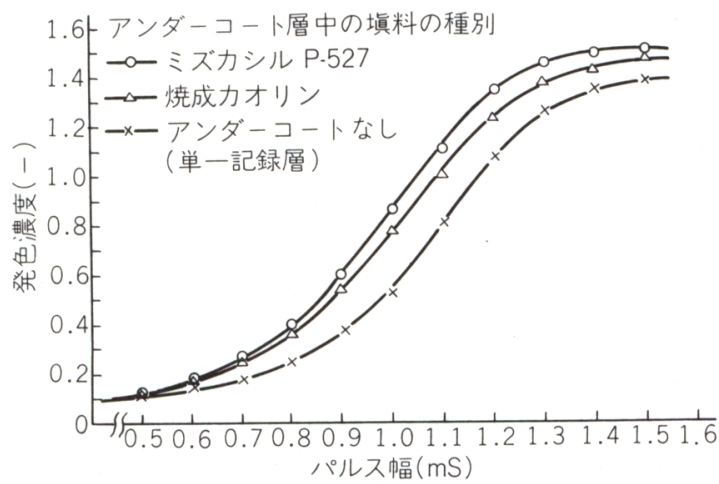

図 14 記録層にミズカシル P-527 を使用し，ア ンダーコート層には $\mathrm{P}-527$ と達成カオリ ンを用いた場合の動的発色特性の改善効 果 
表 4 ミズカシル P-527 をアンダーコート層に 用いた感熱記録紙の特性評価結果

\begin{tabular}{|c|c|c|c|c|}
\hline & $\begin{array}{l}\text { シズカ } \\
\text { シル } \\
\mathrm{P}-527\end{array}$ & $\begin{array}{l}\text { 感熱記録 } \\
\text { 紙用焼成 } \\
\text { カオリン }\end{array}$ & $\begin{array}{l}\text { 感熱記録紙 } \\
\text { 用軽質炭酸 } \\
\text { カルシウム }\end{array}$ \\
\hline \multirow{2}{*}{\multicolumn{2}{|c|}{$\begin{array}{l}\text { 平滑度（秒） } \\
\text { 地肌污れ }\end{array}$}} & 710 & 630 & 456 \\
\hline & & 0.12 & 0.12 & 0.12 \\
\hline \multirow{2}{*}{$\begin{array}{l}\text { 保 } \\
\text { 存 } \\
\text { 性 }\end{array}$} & $60^{\circ} \mathrm{C} \times 24 \mathrm{Hrs}$ & 0.13 & 0.14 & 0.13 \\
\hline & $\begin{array}{c}\text { R.H. } 90 \% \times \\
24 \text { Hrs }\end{array}$ & 0.12 & 0.13 & 0.12 \\
\hline \multirow{2}{*}{\multicolumn{2}{|c|}{$\begin{array}{l}\text { 力又付着防止効果 } \\
\text { 印字特性 }\end{array}$}} & (a) & $\triangle$ & $\triangle$ \\
\hline & & (a) & $\bigcirc$ & $\triangle$ \\
\hline
\end{tabular}

表 5 焼成カオリンをアンダーコート層に用いた 感熱記録紙の特性評価結果

\begin{tabular}{|c|c|c|c|c|}
\hline & $\begin{array}{l}\text { シズカ } \\
\text { シル } \\
\mathrm{P}-527\end{array}$ & $\begin{array}{l}\text { 感熱記録 } \\
\text { 紙用焼成 } \\
\text { カオリン }\end{array}$ & $\begin{array}{l}\text { 感熱記録紙 } \\
\text { 用軽質炭酸 } \\
\text { カルシウム }\end{array}$ \\
\hline \multirow{2}{*}{\multicolumn{2}{|c|}{$\begin{array}{l}\text { 平滑度（秒） } \\
\text { 地肌污れ }\end{array}$}} & 700 & 659 & 430 \\
\hline & & 0.12 & 0.12 & 0.12 \\
\hline \multirow{2}{*}{$\begin{array}{l}\text { 保 } \\
\text { 存 } \\
\text { 性 }\end{array}$} & $60^{\circ} \mathrm{C} \times 24 \mathrm{Hrs}$ & 0.13 & 0.14 & 0.13 \\
\hline & $\begin{array}{l}\text { R.H. } 90 \% \times \\
24 \text { Hrs }\end{array}$ & 0.12 & 0.13 & 0.12 \\
\hline \multirow{2}{*}{\multicolumn{2}{|c|}{$\begin{array}{l}\text { 力又付着防止効果 } \\
\text { 印字特性 }\end{array}$}} & (a) $\sim 0$ & $\triangle$ & $\triangle$ \\
\hline & & (a) $\sim 0$ & $\triangle$ & $\triangle$ \\
\hline
\end{tabular}

し,アンダーコート層にはP-527 と焼成カオリンを用 いた場合の動的発色特性の改善効果を示す。

表 4 にはミズカシル P-527をアンダーコート層に 用いた感熱記録紙の特性評価結果を示す。

表 5 には焼成カオリンをアンダーコート層に用いた 感熱記録紙の特性評価結果を示す。

アンダーコート層を設けた感熱記録紙は単一記録層 型の感熱記録紙に比べ平滑度が上り，サーマルへッド との密着性が改善されると同時に, アンダーコート層 が断熱層として作用しサーマルヘッドからの熱効率 (熱応答性) が向上する。この結果, 発色感度と発色濃 度ともに極めて良好な状態になる。しかし，このよう な場合でもサーマルヘッドへのカス付着防止対策とし て，アンダーコート層と記録層には表面活性が小さく， かつ吸油量の大きな填料を含ませておく必要がある。

アンダーコート層にミズカシル P-527を使用した 場合と焼成カオリンを使用した場合の比較において, 記録層にはいずれも P-527を使用したところ（図 14 参照), 両者ともに発色特性に大きな差は見られないも
のの, 前者の方が発色感度が高く, カス付着防止効果 も良いという結果が得られた。

また, 高感度化する目的でミズカシル P-603 をアン ダーコート層に用い, 記録層の方に $\mathrm{P}-527 \mathrm{H}$ を用いる 例があるが，これは構造的に記録層の方に吸油量の大 きい $\mathrm{P}-527 \mathrm{H}$ を使うことによって記録層中の微粉ケ イ酸の添加割合を少なく出来るため, 結果的にロイコ 染料と顕色剂や増感剤などの熱溶融時における反応効 率が高められるためと思われる。

最近，感熱記録紙とサーマルヘッドの間に生じるス テッキング現象を定量的に測定しようという試みがあ ク，ステッキングが最初に影響を及ぼすと見られる感 熱記録紙の紙送りのためのステッピングモーターの負 荷増をトルク測定によって求めている ${ }^{10)}$ 。

このような研究と共に, サーマルヘッドによる熱溶 融物の物性解明も待たれており, 今後力ス付着防止や ステッキング防止に役立つものと見られている。

\section{4 微粉シリカ以外の感熱記録紙用媜剤}

著者等は上記微粉シリカの他に, それぞれ特徵のあ る感熱記録紙用坥剤を開発している。

例えば，官能性アミノ基含有成分とホルムアルデヒ ド成分とを実質上等モル比で触媒の存在下で縮合して 得られるアミノ樹脂の微粒子で, $20 \sim 90 \mathrm{ml} / 100 \mathrm{~g}$ の 吸油量と $20 \mathrm{~m}^{2} / \mathrm{g}$ 以下の比表面積とを有するもの ${ }^{11)}$, ヘミモルファイト又はウイレマイト構造のケイ酸亜鉛 から成る填㓮 ${ }^{12)}$, そして非晶質ケイ酸アルミニウム微 粒子 $\left(\mathrm{SiO}_{2}=45 \sim 65 \%, \mathrm{Al}_{2} \mathrm{O}_{3}=30 \sim 50 \%\right.$, Ig-Loss $=$ $5 \%$ 以下, 酸強度関数が +1.5 までの固体酸量 $=0.035$ ミリ当量 $/ \mathrm{g}$ 以下, 吸油量 $=50 \mathrm{ml} / 100 \mathrm{~g}$ 以上, Coulter Counter 法によるメジアン径 $=4.0 \mu \mathrm{m}$ 以下, ハンター 白色度 $=75 \%$ 以上，見掛比重 $=0.20 \sim 0.50 \mathrm{~g} / \mathrm{ml})$, お よびこのケイ酸アルミニウムと非晶質シリカ微粒子 (吸油量 $=80 \mathrm{ml} / 100 \mathrm{~g}$ 以上, 比表面積 $=30 \mathrm{~m}^{2} / \mathrm{g}$ 以上) をそれぞれ $100 ： 5$ 100：100の重量比で含む均質組 成物から成る填剂 ${ }^{13)}$ などが上げられる。

これらはいずれもカス付着防止および地肌污れ抑制 やサーマルヘッドとのマッチング性を十分に向上させ るものである。

\section{5. ま と め}

ファクシミリは今後も総合デジタル通信網 (ISDN) の進展，ハードの低価格品の開発などによりさらに普 及してゆくものと予想され，それに伴う感熱記録紙の 需要拡大が期待される。一方, 普通紙使用の G IVファ クシミリの普及動向は感熱記録紙システムを推進する 側にとって気になるところであるが，感熱記録の持つ 
多くの優位性 (ハードの小型化, メンテナンスフリー, トータルコストなど) から, 感熱記録紙は G IIIおよび G IVファクシミリを中心に今後更に伸びるものと予想 されている。

現在, 感熱記録紙の改善課題は保存性の向上, 超高 感度化, 低コスト化などであり, それぞれ素材の選択 を含めた総合的な評価・検討が進められている。

本稿では感熱記録紙に使われる微粉シリカの特性と その機能を紹介したが, この微粉シリカの果たす役割 は重要であり, 更に新たな視点からの機能性付与も求 められている。

今後, 感熱記録紙の分野で微粉シリカを中心とした 素材が更に貢献できることに期待するものである。

\section{参考文献}

1) ペーパーセールスエンジニアリング・シリーズ 4 ; 新・情報産業用紙, 紙業夕イムス社, 218(1984)

2）志賀 喬; 紙パルプ技術夕イムス，27 (8)，34
(1984)

3）特開昭 59-22794（水澤化学）

4）特開昭 59-26292（三菱製紙）

5）特開昭 59-133093 (水澤化学)

6）特公昭 61-56118（神崎製紙）

7）特開昭 63-21180 (リコー)

8）通商産業省化学工業局プロセスフロシート研究会 編; 製造工程困全集第 1 巻, 化学工業社, 352 (1968)

9) R. K. ILER ; THE CHEMISTRY OF SILICA, A Wiley-Interscience Publication JOHN WILEY \& SONS (1979)

10）兵頭建二; 紙パルプ技術夕イムス，32(5)，32 (1989)

11）特開昭 60-58890（水澤化学）

12）特開昭 61-86284（水澤化学)

13）特開昭 64-90787 (水澤化学) 